\title{
Molecular diagnosis of patients affected by mucopolysaccharidosis: a multicenter study
}

\author{
Alessandra Zanetti ${ }^{1,2}$ - Francesca D'Avanzo ${ }^{1,2}$ - Laura Rigon ${ }^{1,2}$. Angelica Rampazzo ${ }^{1}$ - Daniela Concolino ${ }^{3}$. \\ Rita Barone ${ }^{4}$. Nicola Volpi ${ }^{5}$. Lucia Santoro ${ }^{6}$. Susanna Lualdi ${ }^{7}$. Francesca Bertola ${ }^{8}$. Maurizio Scarpa ${ }^{1,2}$. \\ Rosella Tomanin ${ }^{1,2}$
}

Received: 18 October 2018 / Revised: 5 February 2019 / Accepted: 6 February 2019 / Published online: 26 February 2019

(C) The Author(s) 2019

\begin{abstract}
Mucopolysaccharidoses (MPS) are a subgroup of 11 monogenic lysosomal storage disorders due to the deficit of activity of the lysosomal hydrolases deputed to the degradation of mucopolysaccharides. Although individually rare, all together they account for at least 1:25,000 live births. In this study, we present the genetic analysis of a population of 71 MPS patients enrolled in a multicenter Italian study. We re-annotated all variants, according to the latest recommendations, and re-classified them as suggested by the American College of Medical Genetics and Genomics. Variant distribution per type was mainly represented by missense mutations. Overall, 10 patients had received no molecular diagnosis, although 6 of them had undergone either HSCT or ERT, based on clinical and enzymatic evaluations. Moreover, nine novel variants are reported.

Conclusions: Our analysis underlines the need to complete the molecular diagnosis in patients previously diagnosed only on a biochemical basis, suggests a periodical re-annotation of the variants and solicits their deposition in public databases freely available to clinicians and researchers. We strongly recommend a molecular diagnosis based on the analysis of the "trio" instead of the sole proband. These recommendations will help to obtain a complete and correct diagnosis of mucopolysaccharidosis, rendering also possible genetic counseling.
\end{abstract}

Communicated by Peter de Winter

Electronic supplementary material The online version of this article (https://doi.org/10.1007/s00431-019-03341-8) contains supplementary material, which is available to authorized users.

Rosella Tomanin

rosella.tomanin@unipd.it

Alessandra Zanetti

alessandra.zanetti@unipd.it

Francesca D'Avanzo

francesca_davanzo@yahoo.it

Laura Rigon

laura.rigon@unipd.it

Angelica Rampazzo

angelica.rampazzo@gmail.com

Daniela Concolino

dconcolino@unicz.it

Rita Barone

rbarone@iol.it

\author{
Nicola Volpi \\ nicola.volpi@unimore.it \\ Lucia Santoro \\ lucia.santoro@ospedaliriuniti.marche.it \\ Susanna Lualdi \\ susannalualdi@iol.it \\ Francesca Bertola \\ genemonza@unimib.it \\ Maurizio Scarpa \\ maurizio.scarpa@unipd.it
}

Extended author information available on the last page of the article 


\section{What is known}

- MPS are a group of 11 metabolic genetic disorders due to deficits of enzymes involved in the mucopolysaccharides degradation.

- Molecular analysis is commonly performed to confirm enzymatic assays.

What is new

- Eighty-six percent of the 71 patients we collected received a molecular diagnosis; among them, 9 novel variants were reported.

- We stress the importance of molecular diagnosis in biochemically diagnosed patients, encourage a periodical re-annotation of variants according to the recent nomenclature and their publication in open databases.

Keywords Lysosomal storage disorders · Mucopolysaccharidoses · Genetics analyses · Genotype-phenotype correlation · ACMG classification

$\begin{array}{ll}\begin{array}{l}\text { Abbreviations } \\ \text { ACMG }\end{array} & \begin{array}{l}\text { American College of Medical Genetics } \\ \text { and Genomics }\end{array} \\ \text { CNV } & \text { Copy number variations } \\ \text { ERT } & \text { Enzyme replacement therapy } \\ \text { GAG } & \text { Glycosaminoglycans } \\ \text { HGVS } & \text { Human Genome Variation Society } \\ \text { HSCT } & \text { Hematopoietic stem cells transplantation } \\ \text { MPS } & \text { Mucopolysaccharidosis(es) } \\ \text { WES } & \text { Whole exome sequencing } \\ \text { WGS } & \text { Whole genome sequencing }\end{array}$

\section{Introduction}

Mucopolysaccharidoses (MPS) are very rare, monogenic, metabolic disorders due to the deficit of the lysosomal enzymes normally degrading mucopolysaccharides or glycosaminoglycans (GAG), this causing their pathological accumulation in most tissues and organs. GAG accumulation progressively leads to cell dysfunction and death causing impairment of most organ/systems, including the brain in about two-thirds of the cases.

Incidence of MPS varies for each disorder and in different populations and ethnic groups, with overall prevalence going from 1.2 up to 16.9 over 100,000 live births recorded in the USA and Saudi Arabia, respectively [32].

MPS diagnosis normally proceeds from clinical suspicion, going through biochemical analysis, including urinary GAG and enzymatic assays, and is confirmed by molecular diagnosis [21].

Beyond symptomatic therapies, in the last $10-15$ years treatment of these disorders has been mainly accomplished by enzyme supplementation, the so-called enzyme replacement therapy (ERT), available for MPS I, MPS II, MPS IVA, and MPS VI. Also, hematopoietic stem cell transplantation (HSCT) has been successfully applied almost exclusively to MPS I, while still debated for other MPS [9]. In addition to commonly requiring weekly hospitalization, ERT is an expensive procedure implicating important investments from the National Health Care Systems. Therefore, ethical and economic reasons impose its application to patients with a definite diagnosis.

In this study, we collected and evaluated the molecular diagnosis of a group of MPS patients enrolled in a multicenter Italian study, underlining its importance, together with enzymatic assays, to confirm the MPS clinical suspect and to reach a correct diagnosis. Importantly, a definite molecular diagnosis represents an essential tool for effective genetic counseling.

\section{Materials and methods}

Seventy-one subjects affected by MPS were enrolled in a multicenter Italian study, financed by the Italian Ministry of Education, University and Research (MIUR), planning, among others, the collection of clinical, biochemical, and molecular data during a follow-up evaluation. All procedures performed were in accordance with the ethical standards of the institutional research committee and with the 1964 Helsinki declaration and its later amendments. Informed consent was obtained from all individual participants included in the study. Here, we report data related to genetic diagnoses, which were performed in different laboratories applying, in most cases, standard molecular methods (PCR amplification and Sanger sequencing); in few specific cases, second- or third-level analyses were conducted aiming to detect gross deletions, rearrangements, CNVs, or deep intronic variants. Genetic data was extrapolated from a web-based platform shared among the different units. For the patients with no molecular diagnosis available, molecular genetic analysis was not feasible at the time of enrollment in the present study, as patients' DNA samples were not available. Variants reported in the original diagnostic reports were checked using Name Checker (https://www.mutalyzer.nl/name-checker) and, when necessary, were re-annotated on the basis of the most recent HGVS nomenclature (version 15.11; http://www. hgvs.org/nutnomen/). In addition, the novel missense variants were in silico tested for pathogenicity with four different prediction tools: DANN [47], MutationTaster [52], GERP [16], SIFT [55]; moreover, a structural 
evaluation of the impact of the amino acid substitution on the enzyme structure was performed through the tool HOPE [65]. Finally, all variants were further analyzed, (re-)classified according to the criteria suggested by the American College of Medical Genetics and Genomics (ACMG) [50] and submitted to ClinVar database (https:// www.ncbi.nlm.nih.gov/clinvar/) where they will be publicly available.

\section{Results and discussion}

In the population examined, 16 patients were affected by MPS II (22.5\%), 13 by MPS IIIA (18.3\%), 12 by MPS IVA (16.9\%), 9 by MPS I (12.7\%), 9 by MPS IIIB (12.7\%), 7 by MPS VI (9.9\%), 2 by MPS IIIC, 2 by MPS IVB, and 1 patient was affected by MPS IIID (Table 1). Molecular diagnosis had been performed for 61 subjects out of 71 enrolled in the study (85.9\%). Age at diagnosis varied for the different disorders and severity. Generally, severe forms were diagnosed earlier, likely due to the early appearance of first clinical signs and symptoms. This is evident when different forms are described within the same disease, as in MPS I and MPS II. A significant difference between severe and attenuated forms was registered in our population for MPS I, with an average of 1.1 and 6.3 years at diagnosis respectively. This was also registered for MPS II, with an average of 2.9 and 6.6 years at diagnosis respectively (this last value was calculated excluding patient $\mathrm{P} 14$, a subject presenting a mild phenotype, who was diagnosed at 44.3 years of age).

As for MPS IIIA and MPS IIIB, in our population diagnosis was reached on average around 5 years of age, except in one case of MPS IIIB, reported with an attenuated phenotype, and diagnosed at 18 years of age [23]. Most, if not all, MPS IVA cases were reported as severe and diagnosis was achieved on average at 3.2 years of age. The only 2 cases registered for MPS IVB are both reported with a mild phenotype and were diagnosed around 10 years of age. MPS VI, although commonly not affecting neurological functions, usually presents a severe skeletal phenotype, thus early diagnosis can be obtained. In our population, mean age at diagnosis for MPS VI was 1.8 years.

Distribution of diagnosed patients in the different MPS types is shown in Fig. 1. A missing molecular diagnosis was registered in 4/9 MPS I patients, 2/16 patients affected by MPS II, 1/13 MPS IIIA patients, and 3/9 MPS IIIB patients. Thus, for MPS I and MPS II patients, for whom either HSCT or ERT have been available for several years, a total of 6 out of 25 patients did not receive a molecular definition. Three of them underwent HSCT and 3 underwent ERT, based on clinical and biochemical evaluations. For 4 of them, molecular analysis of the genes was not feasible at the time of diagnosis. For all of them, it was never completed afterward.

As for the MPS IIIA and B patients, 4 of which remained molecularly undiagnosed, we suggest this may be due to the delay with which MPS III patients are sometimes clinically recognized and also to the lack of treatments for all MPSIII, which may cause a limited clinical follow-up with time.

Overall, of the 10 patients with no molecular diagnosis, 7 had been clinically diagnosed 20 or more years ago, while most of the patients $(70 \%)$ with molecular diagnosis came to the clinical observation more recently in the last 15 years. Thus, we could argue that in the past, molecular diagnosis likely did not receive significant attention in the completion of the patient diagnosis, given also the fact that some MPS genes were identified in the early 2000s. Moreover, an evaluation of the timing elapsed between clinical/enzymatic diagnosis and molecular diagnosis showed in general, for all MPS taken together, a delay of about 4.6 years of the molecular diagnosis with respect to the clinical/enzymatic diagnosis, with a range from 0 up to 22 years.

A summary of all identified genotypes is reported in Table 1. Since for some patients, variants had been identified several years ago, we checked all of them and when necessary we re-annotated them according to the most recent HGVS nomenclature. On the whole, we report 87 variants, of which 67 are unique. Nine of the reported variants had never been described in the literature before.

Analysis of the genetic alterations identified in the examined population showed that, as expected, most of the variants were missense (about $70 \%$ ), followed by small deletions $(9 \%)$, large deletions/rearrangements $(7.5 \%)$, splicing $(7.5 \%)$, nonsense $(4.5 \%)$ and sense variants $(1.5 \%)$ (Table 2$)$. In the context of MPS, we need to consider that while small variants may be identified in all disorders, other variants, as complex rearrangements, may be more easily encountered in subjects affected by MPS II due to homologous recombinational events between the iduronate 2 -sulfatase gene $(I D S)$ and its pseudogene (IDS2) [48].

Finally, Fig. 2 shows, for each MPS, the number of patients carrying the variant in hemizygosis or homozygosis. Homozygous mutations have been confirmed in parents for 15 out of 23 homozygous patients, thus excluding the presence of deletions on a single allele. In one case, P27, only the mother was analyzed, while for patient P32, only the sister was analyzed. For patient P69, carrying a homozygous deletion of exon 5 of ARSB gene, the homozygosis status was unequivocally confirmed by mRNA analysis. For the remaining 5 patients, analysis of any parents or relatives was not available. However, for 4 of them parents were consanguineous, rendering unlikely the chances of "apparent homozygosity."

Homozygous patients provide a valuable tool to evaluate the in vivo effect of each specific variant, helping to 


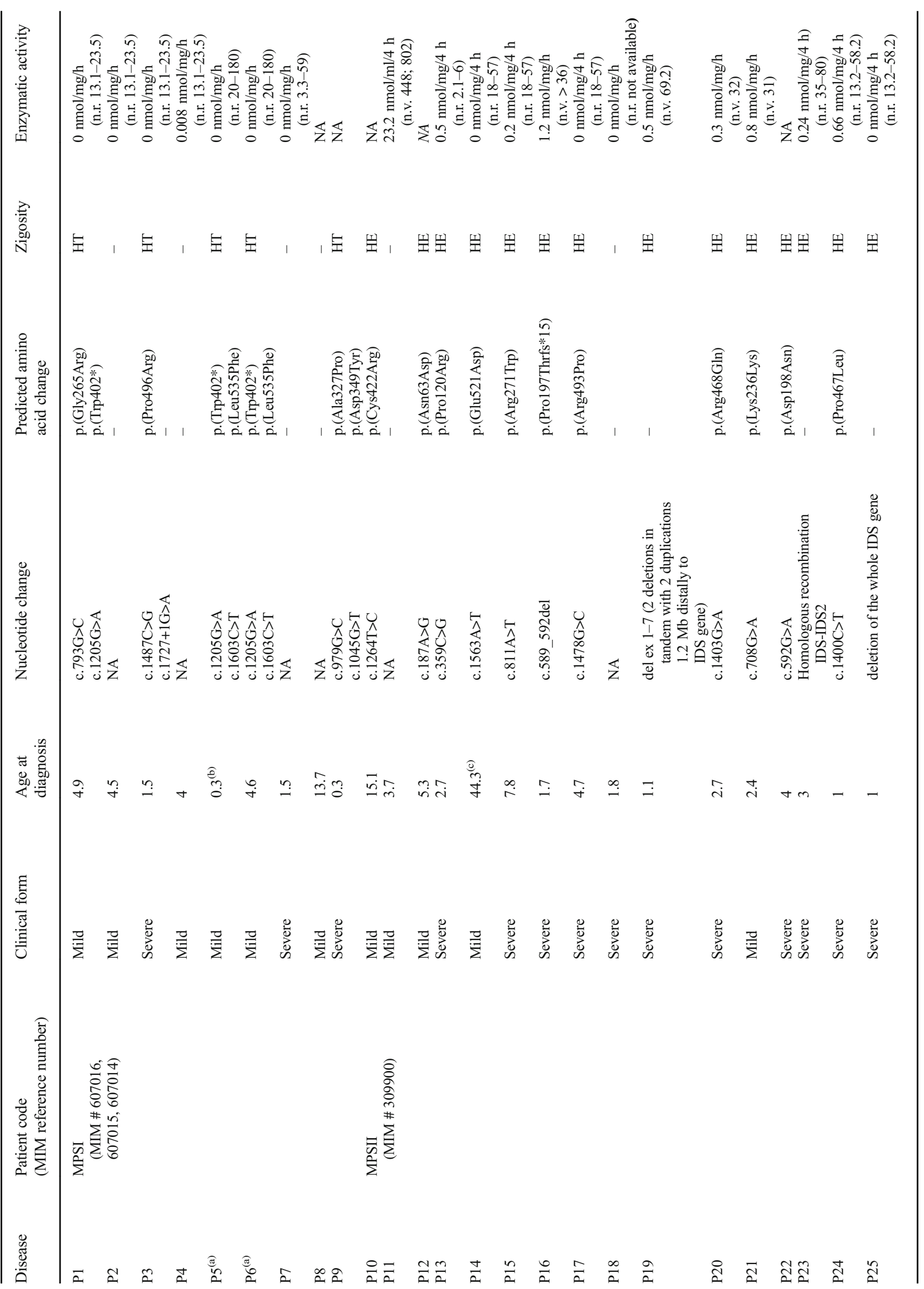




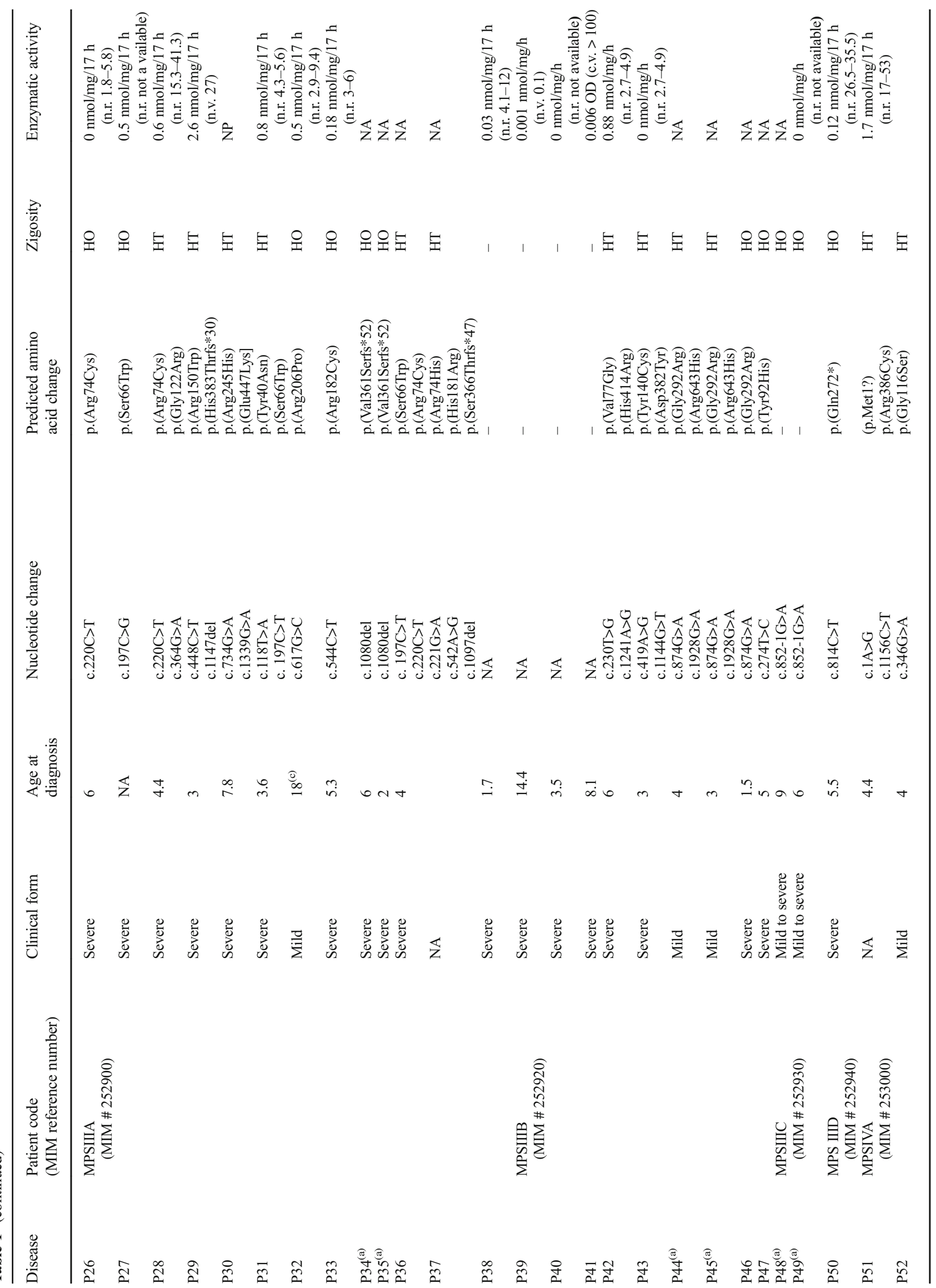




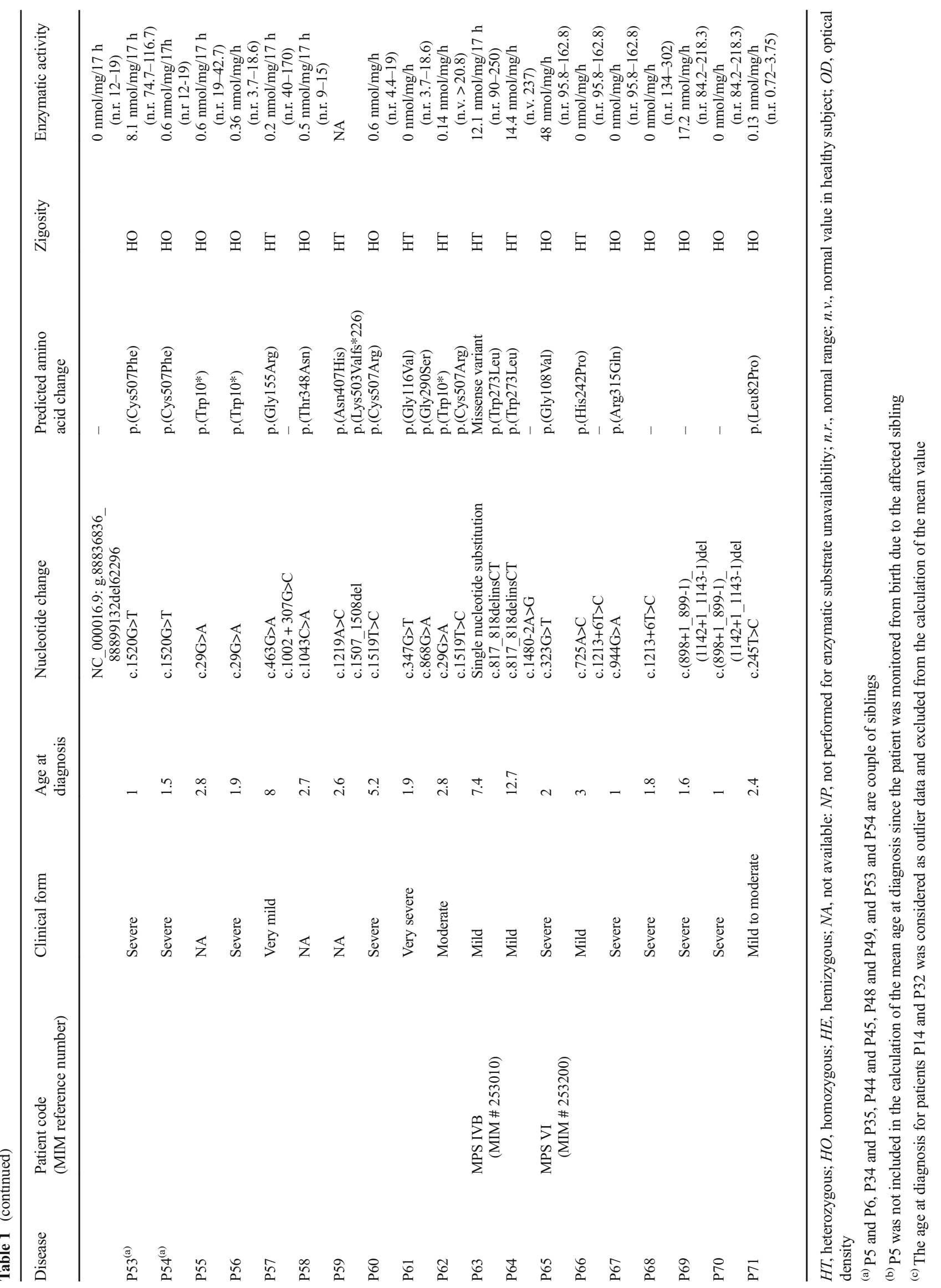


Fig. 1 Number of patients with and without a molecular diagnosis

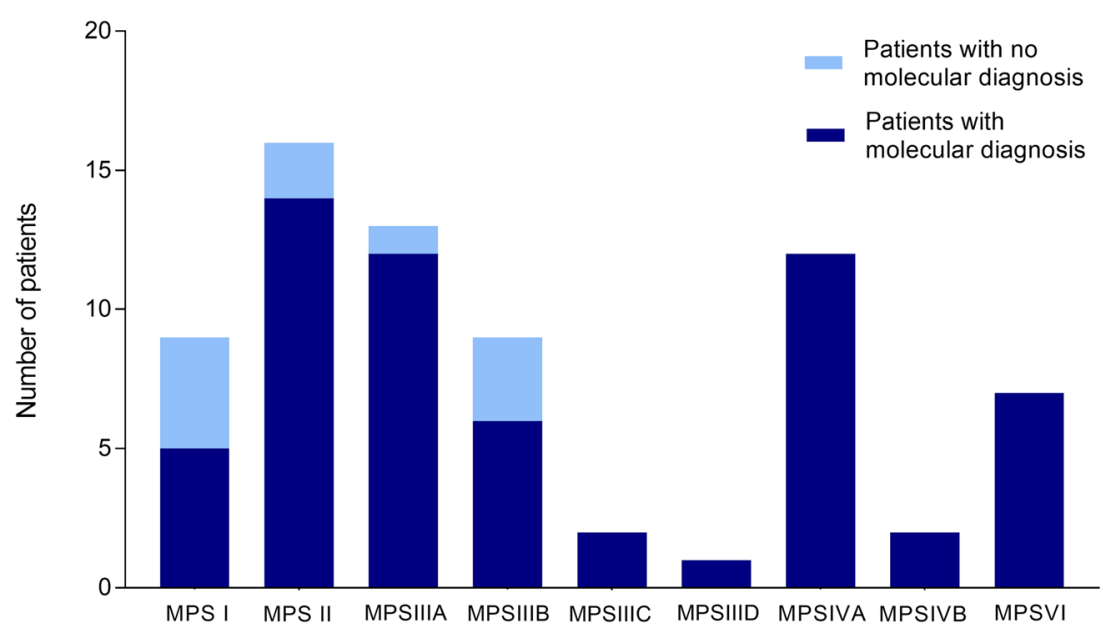

possibly define genotype/phenotype correlations. In this respect, we underline as such evaluations may only be possible based on a strict collaboration between clinics, defining the patient phenotype based on shared severity criteria, and laboratory, carrying out the molecular analysis. In addition, information on parents' ethnicity and consanguinity provided to the laboratory would be very important for the interpretation of the obtained molecular results and for genetic counseling.

Apart from MPS II which, being an X-linked disorder, is always caused by a single pathogenic variant (hemizygous condition), 6/12 of the MPS IIIA as well as 6/12 of the MPS IVA patients presented a condition of homozygosis. Also, 2 MPS IIIB, 2 MPS IIIC, and 1 MPS IIID patients showed a condition of homozygosis. Interestingly, 6 out of the 7 MPS VI patients presented a condition of homozygosity for different pathogenic variants; this reflects a general condition for this disorder in which a wide analysis of the literature has shown that more than $55 \%$ of the patients present genomic homozygosity for different pathogenic variants of the ARSB gene [58].

Eleven of the 23 homozygous patients had consanguineous parents, this explaining homozygosity, in these cases likely independent from the geographical distribution of the variants. It is known that gross deletions or gene rearrangements are commonly associated with severe clinical phenotypes. In our study, this was confirmed in 3 MPS II severe patients, whose causative mutations were represented by the deletion of several exons of the IDS gene (P19 in Table 1), deletion of the whole IDS gene (P25) and an event of homologous recombination between IDS gene and pseudogene (P23). This was also seen in MPS VI, where the deletion of exon 5 of the ARSB gene was associated with a severe phenotype (P69 and P70, Table 1). Table 3 summarizes the phenotypes found in this study in homozygous patients carrying point mutations and those described in the literature with the same variants.
As for the other $11 I D S$ variants identified in this study, mainly represented by missense mutations or small deletions, most of which is previously described, they were in the literature variably associated with either severe or attenuated or mild phenotypes (Table 3 ). Five of them are reported as associated with the same phenotype reported previously in other patients: 2 of them confirming a mild phenotype (P12 and P21 in Table 3) and 3 of them confirming a severe phenotype (P13, P20, and P22 in Table 3). However, the small number of patients analyzed for each variant does not allow drawing conclusions on these genotype-phenotype correlations.

With regards to homozygous patients identified in all MPS, but in MPS I and MPS IVB, a genotype-phenotype correlation analysis was conducted in 6 MPS IIIA patients, 3 of which confirming a previously described phenotype (P26, P34, and P35 in Table 3). For the other 3 homozygotes, no confirmation of previously described phenotypes was possible, thus not allowing to hypothesize any genotype-phenotype correlation. Concerning MPS IVA, 2 homozygous patients out of 6 confirmed previously described severe phenotypes (P56 and P60). Finally, as for MPS VI, none of the homozygotes' phenotypes unequivocally correlated with previously described patients (Table 3), therefore we could not confirm any genotypephenotype correlations. Of the 2 patients showing a mild phenotype, one was carrying in homozygosis the variant c.245T >C (P71 in Table 1), previously undescribed. Other genotype-phenotype correlations for this gene could be inferred indirectly; as for the splicing variant c. $1213+6 \mathrm{~T}>\mathrm{C}$, this was identified in homozygosis in a severe patient and in heterozygosis in a mild patient, compound heterozygote for the variant c. $725 \mathrm{~A}>\mathrm{C}$. This last variant, still presenting "not enough evidence" of pathogenicity according to ACMG classification, could confer the mild phenotype.

In addition, the novel missense variants [IDS: c.811A $>$ T; IDS: c. $1563 \mathrm{~A}>\mathrm{T}$; IDS: c. $542 \mathrm{~A}>\mathrm{G}$, SGSH: c. $542 \mathrm{~A}>\mathrm{G}$, 


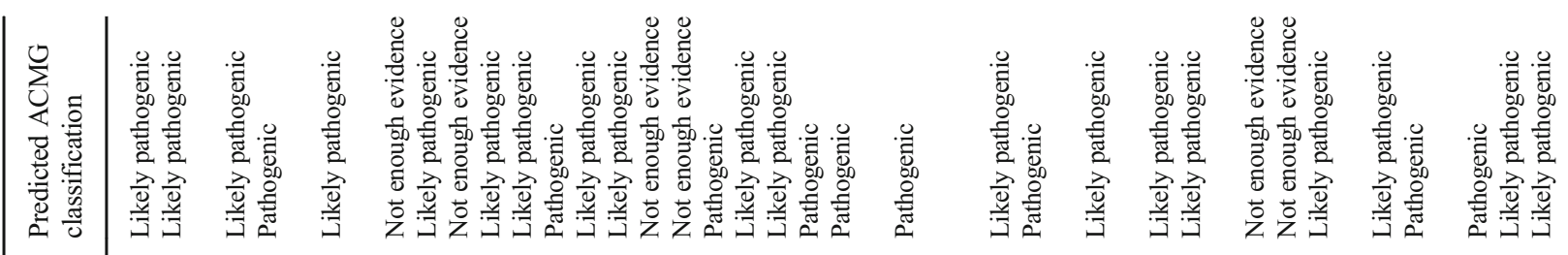

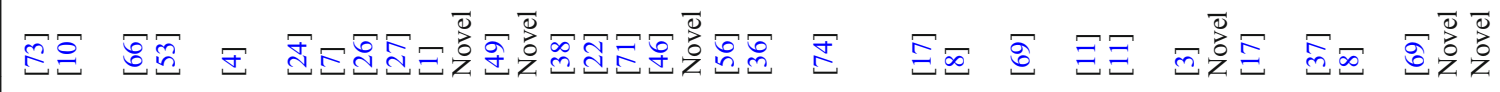

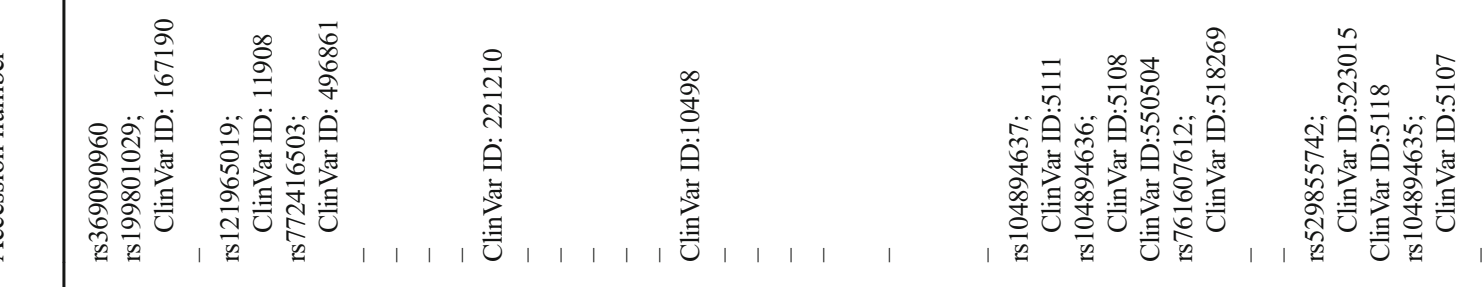

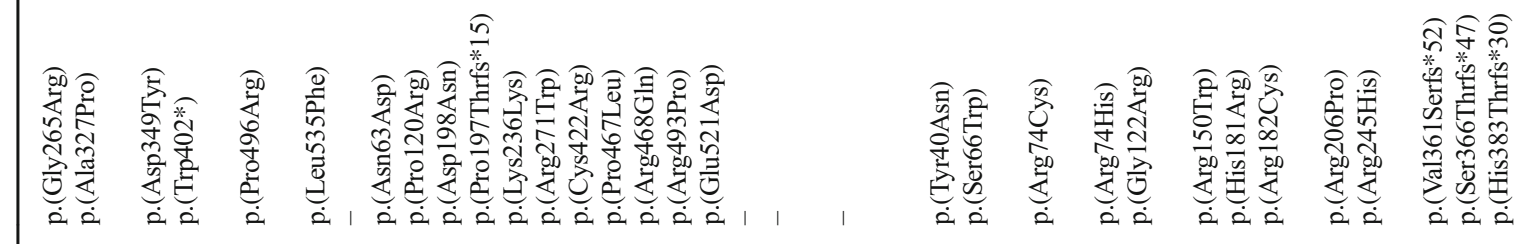

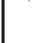
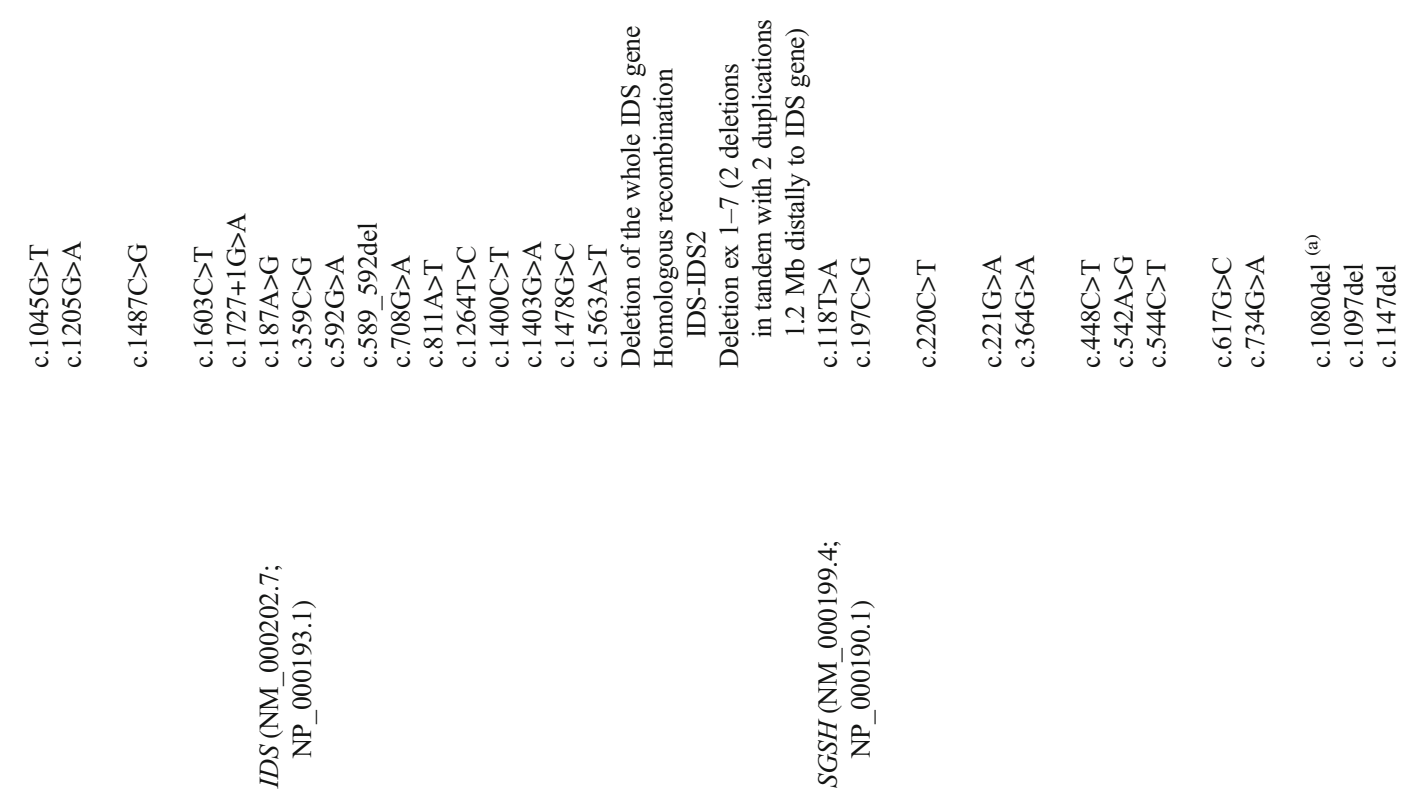

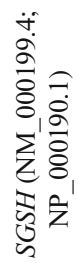




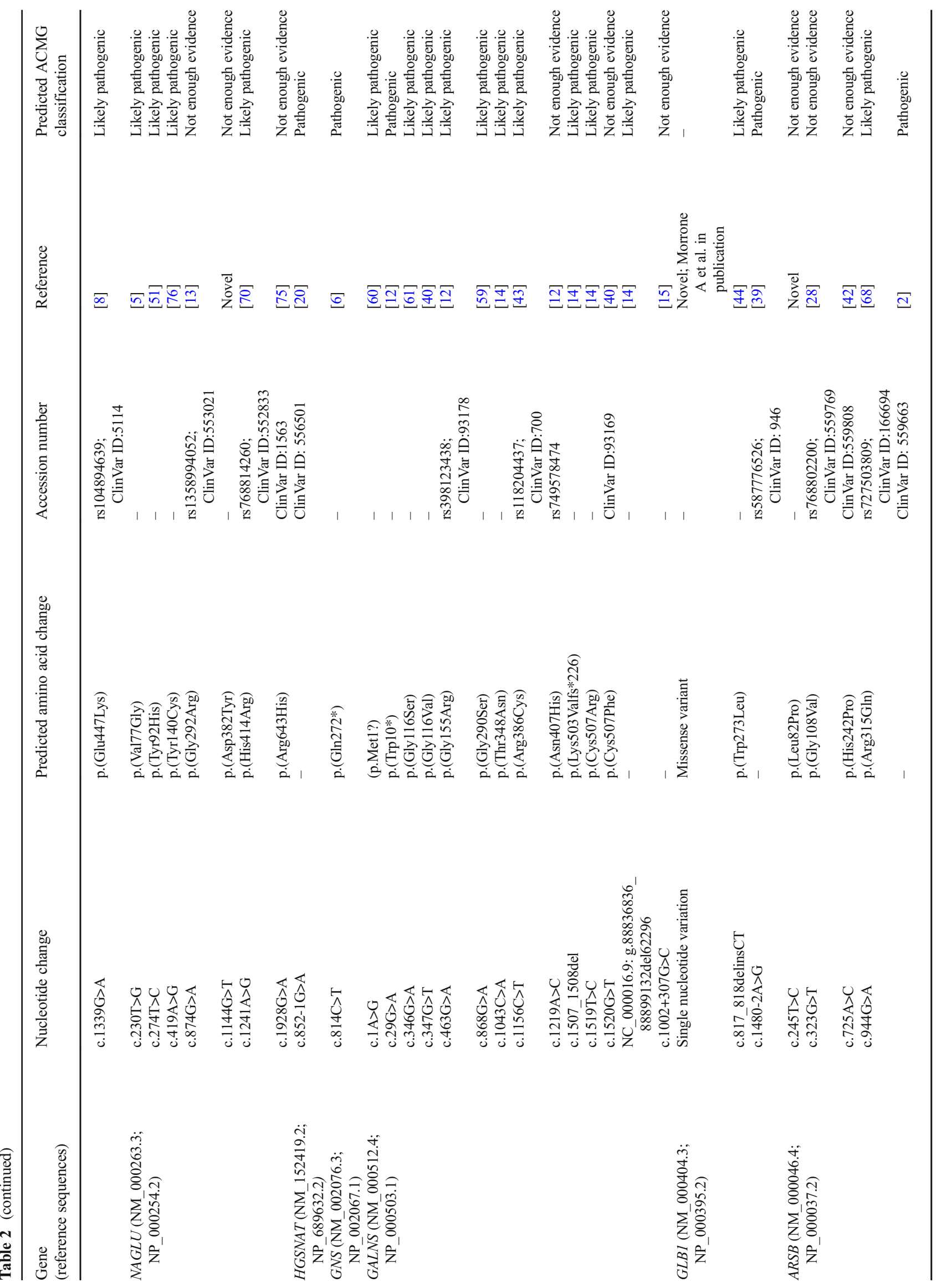


NAGLU: c.1144G>T, and ARSB: c.245T>C] were evaluated for pathogenicity with four different prediction tools (DANN, Mutation Taster, GERP and SIFT) which all confirmed the potential pathogenicity of the tested variants. This was also confirmed by the application of the tool HOPE that predicted potential remarkable structural changes in the enzyme structures which could affect the catalytic activity of the examined proteins. Results of the mentioned in silico evaluations are reported in the Online Resource.

Finally, all variants were re-evaluated according to the recent classification of ACMG (Table 2). The results of this evaluation evidenced that more than half of the variants (almost $56 \%$ ) fell into the "Likely pathogenic" class, $31 \%$ into the "Not enough evidence" class, and the remaining resulted "Pathogenic" (13\%).

\section{Conclusions}

The present study underlines the need to complete the diagnostic workup of MPS patients previously diagnosed on a biochemical basis, through the identification and, possibly, the validation of the related gene variants. Molecular diagnosis is essential to confirm an enzyme deficit and provides diagnostic certainty to disorders for which the application of available treatments requires hospitalization and is extremely expensive. Moreover, we strongly recommend a molecular diagnosis based on the analysis of the "trio" instead of the sole proband, thus allowing the correct definition of the family inheritance and the identification of the de novo variants, which require different counseling. Finally, we suggest a periodical re-annotation of the variants according to the most recent version of HGVS nomenclature and solicit laboratories to perform their deposition in public databases (as LOVD, ClinVar, etc.), freely available to all clinicians and researchers. These recommendations will help obtain a complete and correct diagnosis of mucopolysaccharidosis, rendering also possible genetic counseling.

In these last years, molecular diagnosis of MPS, and in general of monogenic-inherited disorders, has taken advantage of new analytical approaches which have widen the possibility of investigation and have shortened the timing of diagnosis. This includes next-generation sequencing, applied to targeted genes (panels) or, more widely, to exome (whole exome sequencing, WES) or genome analyses (whole genome sequencing, WGS). Moreover, validation of the new genomic variants can now partly take advantage of the availability of several public databases collecting exomic or genomic data from large scale sequencing projects (ExAC, gnomAD, etc.). 
Fig. 2 Number of heterozygous and homozygous/hemizygous patients in each MPS

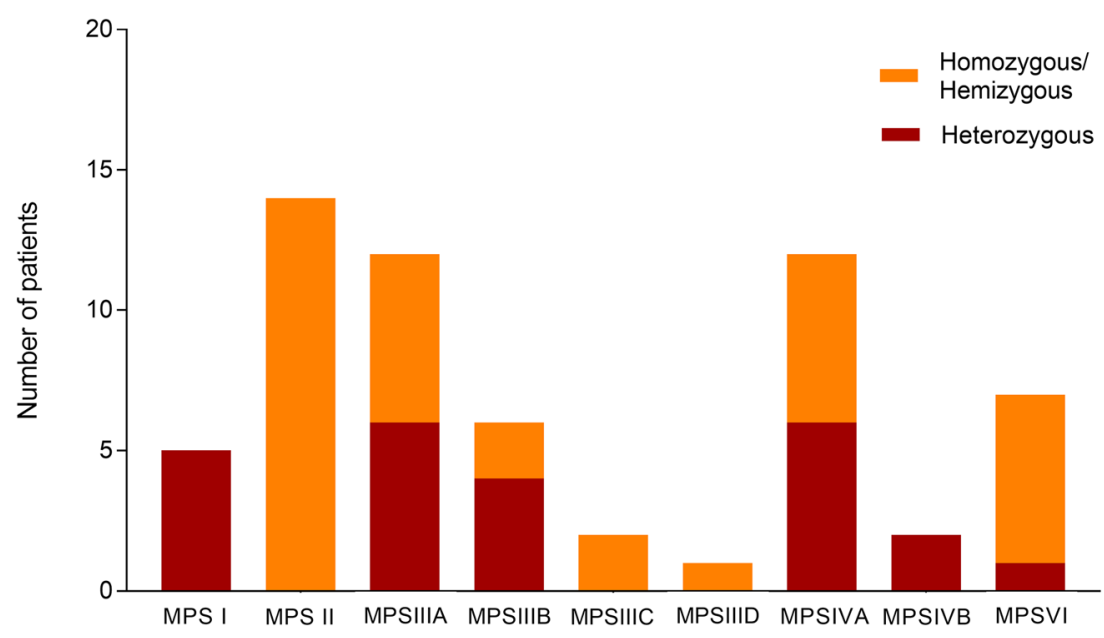

Table 3 List of point mutations found in hemizygosis and homozygosis and the corresponding phenotypes found in our cohort of patients and in the literature

\begin{tabular}{|c|c|c|c|c|}
\hline Gene & Nucleotide change & $\begin{array}{l}\text { Predicted amino } \\
\text { acid change }\end{array}$ & $\begin{array}{l}\text { Phenotypes of homozygous/hemizygous } \\
\text { patients described in our cohort }\end{array}$ & $\begin{array}{l}\text { Phenotypes of homozygous/hemizygous } \\
\text { patients described in literature }\end{array}$ \\
\hline \multirow[t]{8}{*}{ IDS } & c. $187 \mathrm{~A}>\mathrm{G}$ & p.(Asn63Asp) & Mild (P12) & $\begin{array}{l}\text { Mild [26]; intermediate [30]; attenuated [62]; } \\
\text { attenuated [18] }\end{array}$ \\
\hline & c. $359 \mathrm{C}>\mathrm{G}$ & p.(Pro120Arg) & Severe (P13) & Severe to intermediate [27]; severe [33] \\
\hline & c. $592 \mathrm{G}>\mathrm{A}$ & p.(Asp198Asn) & Severe (P22) & Severe [1] \\
\hline & c. $708 \mathrm{G}>\mathrm{A}$ & p.(Lys236Lys) & Mild (P21) & Intermediate [49] \\
\hline & c. $1264 \mathrm{~T}>\mathrm{C}$ & p.(Cys422Arg) & Mild (P10) & severe $[38]$ \\
\hline & c. $1400 \mathrm{C}>\mathrm{T}$ & p.(Pro467Leu) & Severe (P24) & Phenotype not reported [22] \\
\hline & c. $1403 \mathrm{G}>\mathrm{A}$ & p.(Arg468Gln) & Severe (P20) & $\begin{array}{l}\text { Severe [71]; severe [57]; severe [67]; } \\
\quad \text { four severe patients [63]; severe [34]; } \\
\text { three severe patients [35]; severe [31]; } \\
\text { severe [25]; severe [18] }\end{array}$ \\
\hline & c. $1478 \mathrm{G}>\mathrm{C}$ & p.(Arg493Pro) & Severe (P17) & Phenotype not reported [46] \\
\hline \multirow[t]{5}{*}{ SGSH } & c. $197 \mathrm{C}>\mathrm{G}$ & p.(Ser66Trp) & Severe (P27) & $\begin{array}{l}\text { Two severe, three intermediate, one } \\
\text { unknown [17] }\end{array}$ \\
\hline & c. $220 \mathrm{C}>\mathrm{T}$ & p.(Arg74Cys) & Severe (P26) & Severe [41]; unknown [72] \\
\hline & c. $544 \mathrm{C}>\mathrm{T}$ & p.(Arg182Cys) & Severe (P33) & No homozygotes described in literature \\
\hline & c. $617 \mathrm{G}>\mathrm{C}$ & p.(Arg206Pro) & Mild (P32) & $\begin{array}{l}\text { The same patient reported in the present study } \\
\text { was des cribed in [23] }\end{array}$ \\
\hline & c.1080del & p.(Val361Serfs*52) & Severe (P34, P35) & $\begin{array}{l}\text { Severe [69]; three severe patients [37]; } \\
\text { two severe patients [3]; severe [19]; } \\
\text { severe [64] }\end{array}$ \\
\hline \multirow[t]{2}{*}{ NAGLU } & c. $274 \mathrm{~T}>\mathrm{C}$ & p.(Tyr92His) & Severe (P47) & No homozygotes described in literature \\
\hline & c. $874 \mathrm{G}>\mathrm{A}$ & p.(Gly292Arg) & Severe (P46) & No homozygotes described in literature \\
\hline HGSNAT & c. $852-1 \mathrm{G}>\mathrm{A}$ & - & Mild to severe (P48, P49) & $\begin{array}{l}\text { The same patients reported in the present study } \\
\text { were described in [20] }\end{array}$ \\
\hline GNS & c. $814 \mathrm{C}>\mathrm{T}$ & p. $(\mathrm{Gln} 272 *)$ & Severe (P50) & $\begin{array}{l}\text { The same patient reported in the present study } \\
\text { was described in [6] }\end{array}$ \\
\hline \multirow[t]{3}{*}{ GALNS } & c. $29 \mathrm{G}>\mathrm{A}$ & p. $\left(\operatorname{Trp} 10^{*}\right)$ & Severe (P56) & Unknown [12]; severe [60] \\
\hline & c. $1519 \mathrm{~T}>\mathrm{C}$ & p.(Cys507Arg) & Severe (P60) & Severe $[14]$ \\
\hline & c. $1520 \mathrm{G}>\mathrm{T}$ & p.(Cys507Phe) & Severe (P53, P54) & No homozygotes described in literature \\
\hline \multirow[t]{3}{*}{ ARSB } & c. $323 \mathrm{G}>\mathrm{T}$ & p.(Gly108Val) & Severe (P65) & No homozygotes described in literature \\
\hline & c. $944 \mathrm{G}>\mathrm{A}$ & p.(Arg315Gln) & Severe (P67) & $\begin{array}{l}\text { Intermediate [68]; severe [45]; five patients } \\
\text { with not reported phenotype [29] }\end{array}$ \\
\hline & c. $1213+6 \mathrm{~T}>\mathrm{C}$ & - & Severe (P68) & $\begin{array}{l}\text { The same patient reported in the present study } \\
\text { was described in [42] }\end{array}$ \\
\hline
\end{tabular}


These tools, used with the appropriate critical evaluation, may now allow more rapid and correct identification and validation of the genomic variants associated with a specific clinical phenotype.

Acknowledgements Authors are grateful to patients and their families who accepted to be enrolled in the multicenter study. A special acknowledgement to Prof. Orazio Gabrielli, [Department of Clinical Sciences, Division of Pediatrics, Polytechnic University of Marche, Ospedali Riuniti, Presidio Salesi, Ancona (Italy)], who coordinated the Italian multicenter study.

Authors' contributions AZ collected and analyzed patients' genetic data and wrote the manuscript; AR, DC, RB, and LS collected genetic data of their clinical centers and critically revised the manuscript; FD, LR, NV, $\mathrm{SL}$, and FB performed some genetic analysis, gave support to genetic data analysis, and critically revised the manuscript; MS critically revised the manuscript; RT analyzed patients genetic data and wrote the manuscript. All authors read and approved the final version of the manuscript.

Funding information This work was financed by the Italian Ministry of Education, University and Research (MIUR), PRIN 2012 Prot. 20122EK9SZ.

\section{Compliance with ethical statements}

Conflict of interest MS received educational grants and travel grants from BioMarin, Chiesi, Genzyme, and Shire. DC received travel grants from BioMarin, Genzyme, and Shire. AZ, FD, LR, AR, RB, NV, LS, SL, $\mathrm{FB}$, and RT declare no conflicts of interest.

Ethical approval All procedures involving humans performed in the study were in accordance with the ethical standards of the institutional research committee and with the 1964 Helsinki declaration and its later amendments.

Informed consent Informed consent was obtained from all individual participants included in the study.

Open Access This article is distributed under the terms of the Creative Commons Attribution 4.0 International License (http:// creativecommons.org/licenses/by/4.0/), which permits unrestricted use, distribution, and reproduction in any medium, provided you give appropriate credit to the original author(s) and the source, provide a link to the Creative Commons license, and indicate if changes were made.

\section{References}

1. Amartino H, Ceci R, Masllorens F, Gal A, Arberas C, Bay L, Ilari R, Dipierri J, Specola N, Cabrera A, Rozenfeld P (2014) Identification of 17 novel mutations in 40 Argentinean unrelated families with mucopolysaccharidosis type II (Hunter syndrome). Mol Genet Metab Reports 1:401-406

2. Arlt G, Brooks DA, Isbrandt D, Hopwood JJ, Bielicki J, Bradford TM, Bindloss-Petherbridge CA, von Figura K, Peters C (1994) Juvenile form of mucopolysaccharidosis VI (Maroteaux-Lamy syndrome). A
C-terminal extension causes instability but increases catalytic efficiency of arylsulfatase B. J Biol Chem 269(13):9638-9643

3. Beesley CE, Young EP, Vellodi A, Winchester BG (2000) Mutational analysis of Sanfilippo syndrome type A (MPS IIIA): identification of 13 novel mutations. J Med Genet 37(9):704-717

4. Beesley CE, Meaney CA, Greenland G, Adams V, Vellodi A, Young EP, Winchester BG (Nov. 2001) Mutational analysis of 85 mucopolysaccharidosis type I families: frequency of known mutations, identification of 17 novel mutations and in vitro expression of missense mutations. Hum Genet 109(5):503-511

5. Beesley CE, Jackson M, Young EP, Vellodi A, Winchester BG (2005) Molecular defects in Sanfilippo syndrome type B (mucopolysaccharidosis IIIB). J Inherit Metab Dis 28(5):759-767

6. Beesley CE, Concolino D, Filocamo M, Winchester BG, Strisciuglio P (2007) Identification and characterisation of an $8.7 \mathrm{~kb}$ deletion and a novel nonsense mutation in two Italian families with Sanfilippo syndrome type D (mucopolysaccharidosis IIID). Mol Genet Metab 90(1):77-80

7. Bertola F, Filocamo M, Casati G, Mort M, Rosano C, TylkiSzymanska A, Tüysüz B, Gabrielli O, Grossi S, Scarpa M, Parenti G, Antuzzi D, Dalmau J, Di Rocco M, Dionisi Vici C, Okur I, Rosell J, Rovelli A, Furlan F, Rigoldi M, Biondi A, Cooper DN, Parini R (2011) IDUA mutational profiling of a cohort of 102 European patients with mucopolysaccharidosis type I: identification and characterization of 35 novel $\alpha$-L-iduronidase (IDUA) alleles. Hum Mutat 32(6):E2189-E2210

8. Blanch L, Weber B, Guo XH, Scott HS, Hopwood JJ (1997) Molecular defects in Sanfilippo syndrome type A. Hum Mol Genet 6(5):787-791

9. Boelens J, van Hasselt P (2016) Neurodevelopmental outcome after hematopoietic cell transplantation in inborn errors of metabolism: current considerations and future perspectives. Neuropediatrics 47(05):285-292

10. Bunge S, Kleijer WJ, Steglich C, Beck M, Schwinger E, Gal A (1995) Mucopolysaccharidosis type I: identification of 13 novel mutations of the $\alpha$-L-iduronidase gene. Hum Mutat 6(1):91-94

11. Bunge S, Ince H, Steglich C, Kleijer WJ, Beck M, Zaremba J, van Diggelen OP, Weber B, Hopwood JJ, Gal A (1997) Identification of 16 sulfamidase gene mutations including the common $\mathrm{R} 74 \mathrm{C}$ in patients with mucopolysaccharidosis type IIIA (Sanfilippo A). Hum Mutat 10(6):479-485

12. Bunge S, Kleijer WJ, Tylki-Szymanska A, Steglich C, Beck M, Tomatsu S, Fukuda S, Poorthuis BJHM, Czartoryska B, Orii T, Gal A (1997) Identification of 31 novel mutations in the Nacetylgalactosamine-6- sulfatase gene reveals excessive allelic heterogeneity among patients with Morquio A syndrome. Hum Mutat 10(3):223-232

13. Bunge S, Knigge A, Steglich C, Kleijer WJ, van Diggelen OP, Beck M, Gal A. (1999) Mucopolysaccharidosis type IIIB (Sanfilippo B): identification of 18 novel alpha-N-acetylglucosaminidase gene mutations. J Med Genet 36(1):28-31

14. Caciotti A, Tonin R, Rigoldi M, Ferri L, Catarzi S, Cavicchi C, Procopio E, Donati MA, Ficcadenti A, Fiumara A, Barone R, Garavelli L, Rocco MD, Filocamo M, Antuzzi D, Scarpa M, Mooney SD, Li B, Skouma A, Bianca S, Concolino D, Casalone R, Monti E, Pantaleo M, Giglio S, Guerrini R, Parini R, Morrone A (2015) Optimizing the molecular diagnosis of GALNS: novel methods to define and characterize Morquio-A syndrome-associated mutations. Hum Mutat 36(3):357-368

15. Caciotti A, Tonin R, Mort M, Cooper DN, Gasperini S, Rigoldi M, Parini R, Deodato F, Taurisano R, Sibilio M, Parenti G, Guerrini R, Morrone A. (2018) Mis-splicing of the GALNS gene resulting from deep intronic mutations as a cause of Morquio a disease. BMC Med Genet 19(1):183

16. Cooper GM, Stone EA, Asimenos G, NISC Comparative Sequencing Program, Green ED, Batzoglou S, Sidow A (2005) 
Distribution and intensity of constraint in mammalian genomic sequence. Genome Res 15(7):901-913

17. Di Natale P, Balzano N, Esposito S, Villani GRD (1998) Identification of molecular defects in Italian Sanfilippo a patients including 13 novel mutations. Hum Mutat 11(4):313-320

18. Dvorakova L, Vlaskova H, Sarajlija A, Ramadza DP, Poupetova H, Hruba E, Hlavata A, Bzduch V, Peskova K, Storkanova G, Kecman B, Djordjevic M, Baric I, Fumic K, Barisic I, Reboun M, Kulhanek J, Zeman J, Magner M (2017) Genotype-phenotype correlation in 44 Czech, Slovak, Croatian and Serbian patients with mucopolysaccharidosis type II. Clin Genet 91(5):787-796

19. Esposito S, Balzano N, Daniele A, Villani GRD, Perkins K, Weber B, Hopwood JJ, di Natale P (2000) Heparan N-sulfatase gene: two novel mutations and transient expression of 15 defects. Biochim Biophys Acta 1501(1):1-11

20. Fedele AO, Filocamo M, Di Rocco M, Sersale G, Lübke T, di Natale P, Cosma MP, Ballabio A. (2007) Mutational analysis of the HGSNAT gene in Italian patients with mucopolysaccharidosis IIIC (Sanfilippo C syndrome). Mutation in brief \#959. Online. Hum Mutat 28(5):523

21. Filocamo M, Morrone A (2011) Lysosomal storage disorders: molecular basis and laboratory testing. Hum Genomics 5(3):156-169

22. Froissart R, Maire I, Millat G, Cudry S, Birot AM, Bonnet V, Bouton O, Bozon D (1998) Identification of iduronate sulfatase gene alterations in 70 unrelated Hunter patients. Clin Genet 53(5):362-368

23. Gabrielli O, Coppa GV, Bruni S, Villani GRD, Pontarelli G, Di Natale P (2005) An adult Sanfilippo type A patient with homozygous mutation R206P in the sulfamidase gene. Am J Med Genet A 133A(1):85-89

24. Gabrielli O, Clarke LA, Bruni S, Coppa GV (2010) Enzymereplacement therapy in a 5-month-old boy with attenuated presymptomatic MPS I: 5-year follow-up. Pediatrics 125(1):e183-e187

25. Galvis J, González J, Uribe A, Velasco H (2015) Deep genotyping of the IDS gene in Colombian patients with Hunter syndrome. JIMD Rep 19:101-109

26. Goldenfum SL, Young E, Michelakakis H, Tsagarakis S, Winchester B (1996) Mutation analysis in 20 patients with Hunter disease. Hum Mutat 7(1):76-78

27. Hopwood JJ, Bunge S, Morris CP, Wilson PJ, Steglich C, Beck M, Schwinger E, Gal A (1993) Molecular basis of mucopolysaccharidosis type II: mutations in the iduronate-2-sulphatase gene. Hum Mutat 2(6): 435-442

28. Karageorgos L, Brooks DA, Harmatz P, Ketteridge D, Pollard A, Melville EL, Parkinson-Lawrence E, Clements PR, Hopwood JJ (2007) Mutational analysis of mucopolysaccharidosis type VI patients undergoing a phase II trial of enzyme replacement therapy. Mol Genet Metab 90(2):164-170

29. Karageorgos L, Brooks DA, Pollard A, Melville EL, Hein LK, Clements PR, Ketteridge D, Swiedler SJ, Beck M, Giugliani R, Harmatz P, Wraith JE, Guffon N, Leão Teles E, Sá Miranda MC, Hopwood JJ (2007) Mutational analysis of 105 mucopolysaccharidosis type VI patients. Hum Mutat 28(9):897-903

30. Karsten S, Voskoboeva E, Tishkanina S, Pettersson U, Krasnopolskaja X, Bondeson ML (1998) Mutational spectrum of the iduronate-2-sulfatase (IDS) gene in 36 unrelated Russian MPS II patients. Hum Genet 103(6):732-735

31. Keeratichamroen S, Cairns JR, Wattanasirichaigoon D, Wasant P, Ngiwsara L, Suwannarat P, Pangkanon S, Kuptanon J, Tanpaiboon P, Rujirawat T, Liammongkolkul S, Svasti J (2008) Molecular analysis of the iduronate-2-sulfatase gene in Thai patients with Hunter syndrome. J Inherit Metab Dis 31 Suppl 2(S2):S303-S311

32. Khan SA, Peracha H, Ballhausen D, Wiesbauer A, Rohrbach M, Gautschi M, Mason RW, Giugliani R, Suzuki Y, Orii KE, Orii T, Tomatsu S (Jul. 2017) Epidemiology of mucopolysaccharidoses. Mol Genet Metab 121(3):227-240
33. Kosuga M, Mashima R, Hirakiyama A, Fuji N, Kumagai T, Seo JH, Nikaido M, Saito S, Ohno K, Sakuraba H, Okuyama T (2016) Molecular diagnosis of 65 families with mucopolysaccharidosis type II (Hunter syndrome) characterized by 16 novel mutations in the IDS gene: genetic, pathological, and structural studies on iduronate-2-sulfatase. Mol Genet Metab 118(3):190-197

34. Li P, Bellows AB, Thompson JN (1999) Molecular basis of iduronate2-sulphatase gene mutations in patients with mucopolysaccharidosis type II (Hunter syndrome). J Med Genet 36(1):21-27

35. Lin S-P, Chang J-H, Lee-Chen G-J, Lin D-S, Lin H-Y, Chuang C-K (2006) Detection of hunter syndrome (mucopolysaccharidosis type II) in Taiwanese: biochemical and linkage studies of the iduronate2-sulfatase gene defects in MPS II patients and carriers. Clin Chim Acta 369(1):29-34

36. Manara R, Rampazzo A, Cananzi M, Salviati L, Mardari R, Drigo P, Tomanin R, Gasparotto N, Priante E, Scarpa M. (2010) Hunter syndrome in an 11-year old girl on enzyme replacement therapy with idursulfase: brain magnetic resonance imaging features and evolution. J Inherit Metab Dis 33 Suppl 3(S3):S67-S72

37. Montfort M, Vilageliu L, Garcia-Giralt N, Guidi S, Coll MJ, Chabás A, Grinberg D (1998) Mutation 1091delC is highly prevalent in Spanish Sanfilippo syndrome type a patients. Hum Mutat 12(4):274-279

38. Moreira da Silva I, Froissart R, Marques dos Santos H, Caseiro C, Maire I, Bozon D (2001) Molecular basis of mucopolysaccharidosis type II in Portugal: identification of four novel mutations. Clin Genet 60(4):316-318

39. Morrone A, Bardelli T, Donati MA, Giorgi M, di Rocco M, Gatti R, Parini R, Ricci R, Taddeucci G, D'Azzo A, Zammarchi E (2000) Beta-galactosidase gene mutations affecting the lysosomal enzyme and the elastin-binding protein in GM1-gangliosidosis patients with cardiac involvement. Hum Mutat 15(4):354-366

40. Morrone A, Tylee KL, al-Sayed M, Brusius-Facchin AC, Caciotti A, Church HJ, Coll MJ, Davidson K, Fietz MJ, Gort L, Hegde M, Kubaski F, Lacerda L, Laranjeira F, Leistner-Segal S, Mooney S, Pajares S, Pollard L, Ribeiro I, Wang RY, Miller N (2014) Molecular testing of 163 patients with Morquio A (mucopolysaccharidosis IVA) identifies 39 novel GALNS mutations. Mol Genet Metab 112(2):160-170

41. Muschol N, Storch S, Ballhausen D, Beesley C, Westermann JC, Gal A, Ullrich K, Hopwood JJ, Winchester B, Braulke T (Jun. 2004) Transport, enzymatic activity, and stability of mutant sulfamidase (SGSH) identified in patients with mucopolysaccharidosis type III A. Hum Mutat 23(6):559-566

42. Di Natale P, Villani GR, Parini R, Scarpa M, Parenti G, Pontarelli G, Grosso M, Sersale G, Tomanin R, Sibilio M, Barone R, Fiumara A. (2008) Molecular markers for the follow-up of enzymereplacement therapy in mucopolysaccharidosis type VI disease. Biotechnol Appl Biochem 49(3):219

43. Ogawa T, Tomatsu S, Fukuda S, Yamagishi A, Rezvi GMM, Sukegawa K, Kondo N, Suzuki Y, Shimozawa N, Orii T (1995) Mucopolysaccharidosis IVA: screening and identification of mutations of the $\mathrm{N}$-acetylgalactosamine-6-sulfate sulfatase gene. Hum Mol Genet 4(3):341-349

44. Oshima A, Yoshida K, Shimmoto M, Fukuhara Y, Sakuraba H, Suzuki Y (1991) Human beta-galactosidase gene mutations in Morquio B disease. Am J Hum Genet 49(5):1091-1093

45. Petry MFG, Nonemacher K, Sebben JC, Schwartz IVD, Azevedo ACM, Burin MG, de Rezende AR, Kim CA, Giugliani R, LeistnerSegal S (2005) Mucopolysaccharidosis type VI: identification of novel mutations on the arylsulphatase B gene in South American patients. J Inherit Metab Dis 28(6):1027-1034

46. Pollard LM, Jones JR, Wood TC (2013) Molecular characterization of 355 mucopolysaccharidosis patients reveals 104 novel mutations. J Inherit Metab Dis 36(2):179-187 
47. Quang D, Chen Y, Xie X (2015) DANN: a deep learning approach for annotating the pathogenicity of genetic variants. Bioinformatics 31(5):761-763

48. Rathmann M, Bunge S, Steglich C, Schwinger E, Gal A (1995) Evidence for an iduronate-sulfatase pseudogene near the functional Hunter syndrome gene in Xq27.3-q28. Hum Genet 95(1):34-38

49. Rathmann M, Bunge S, Beck M, Kresse H, Tylki-Szymanska A, Gal A (1996) Mucopolysaccharidosis type II (Hunter syndrome): mutation 'hot spots' in the iduronate-2-sulfatase gene. Am J Hum Genet 59(6):1202-1209

50. Richards S, Aziz N, Bale S, Bick D, Das S, Gastier-Foster J, Grody WW, Hegde M, Lyon E, Spector E, Voelkerding K, Rehm HL; ACMG Laboratory Quality Assurance Committee. (2015) Standards and guidelines for the interpretation of sequence variants: a joint consensus recommendation of the American College of Medical Genetics and Genomics and the Association for Molecular Pathology. Genet Med 17(5):405-424

51. Schmidtchen A, Greenberg D, Zhao HG, Li HH, Huang Y, Tieu P, Zhao HZ, Cheng S, Zhao Z, Whitley CB, di Natale P, Neufeld EF (1998) NAGLU mutations underlying Sanfilippo syndrome type B. Am J Hum Genet 62(1):64-69

52. Schwarz JM, Cooper DN, Schuelke M, Seelow D (2014) MutationTaster2: mutation prediction for the deep-sequencing age. Nat Methods 11(4):361-362

53. Scott HS, Litjens T, Hopwood JJ, Morris CP (1992) A common mutation for mucopolysaccharidosis type I associated with a severe Hurler syndrome phenotype. Hum Mutat 1(2):103-108

54. Scott HS, Blanch L, Guo XH, Freeman C, Orsborn A, Baker E, Sutherland GR, Morris CP, Hopwood JJ (1995) Cloning of the sulphamidase gene and identification of mutations in Sanfilippo A syndrome. Nat Genet 11(4):465-467

55. Sim N-L, Kumar P, Hu J, Henikoff S, Schneider G, Ng PC (2012) SIFT web server: predicting effects of amino acid substitutions on proteins. Nucleic Acids Res 40(W1):W452-W457

56. Steén-Bondeson ML, Dahl N, Tönnesen T, Kleijer WJ, Seidlitz G, Gustavson KH, Wilson PJ, Morris CP, Hopwood JJ, Pettersson U (1992) Molecular analysis of patients with Hunter syndrome: implication of a region prone to structural alterations within the IDS gene. Hum Mol Genet 1(3):195-198

57. Sukegawa K, Tomatsu S, Fukao T, Iwata H, Song XQ, Yamada Y, Fukuda S, Isogai K, Orii T (1995) Mucopolysaccharidosis type II (Hunter disease): identification and characterization of eight point mutations in the iduronate-2-sulfatase gene in Japanese patients. Hum Mutat 6(2):136-143

58. Tomanin R, Karageorgos L, Zanetti A, Al-Sayed M, Bailey M, Miller N, Sakuraba H, Hopwood JJ. (2018) "Mucopolysaccharidosis type VI (MPS VI) and molecular analysis: review and classification of published variants in the ARSB gene." Hum Mutat 39(12):1788-1802

59. Tomatsu S, Fukuda S, Cooper A, Wraith JE, Ferreira P, di Natale P, Tortora P, Fujimoto A, Kato Z, Yamada N, Isogai K, Yamagishi A, Sukegawa K, Suzuki Y, Shimozawa N, Kondo N, Sly WS, Orii T (1997) Fourteen novel mucopolysaccharidosis IVA producing mutations in GALNS gene. Hum Mutat 10(5):368-375

60. Tomatsu S, Filocamo M, Orii KO, Sly WS, Gutierrez MA, Nishioka T, Serrato OP, Natale PD, Montaño AM, Yamaguchi S, Kondo N, Orii T, Noguchi A (2004) Mucopolysaccharidosis IVA (Morquio A): identification of novel common mutations in the Nacetylgalactosamine-6-sulfate sulfatase (GALNS) gene in Italian patients. Hum Mutat 24(2):187-188

61. Tomatsu S, Dieter T, Schwartz IV, Sarmient P, Giugliani R, Barrera LA, Guelbert N, Kremer R, Repetto GM, Gutierrez MA, Nishioka T, Serrato OP, Montaño AM, Yamaguchi S, Noguchi A. (2004) Identification of a common mutation in mucopolysaccharidosis IVA: correlation among genotype, phenotype, and keratan sulfate. J Hum Genet 49(9):490-494
62. Uttarilli A, Ranganath P, Matta D, Md Nurul Jain J, Prasad K, Babu AS, Girisha KM, Verma IC, Phadke SR, Mandal K, Puri RD, Aggarwal S, Danda S, Sankar VH, Kapoor S, Bhat M, Gowrishankar K, Hasan AQ, Nair M, Nampoothiri S, Dalal A (2016) Identification and characterization of 20 novel pathogenic variants in 60 unrelated Indian patients with mucopolysaccharidoses type I and type II. Clin Genet 90(6):496-508

63. Vafiadaki E, Cooper A, Heptinstall LE, Hatton CE, Thornley M, Wraith JE (1998) Mutation analysis in 57 unrelated patients with MPS II (Hunter's disease). Arch Dis Child 79(3):237-241

64. Valstar MJ, Neijs S, Bruggenwirth HT, Olmer R, Ruijter GJG, Wevers RA, van Diggelen OP, Poorthuis BJ, Halley DJ, Wijburg FA (2010) Mucopolysaccharidosis type IIIA: clinical spectrum and genotype-phenotype correlations. Ann Neurol 68(6):876-887

65. Venselaar H, Te Beek TAH, Kuipers RKP, Hekkelman ML, Vriend G (2010) Protein structure analysis of mutations causing inheritable diseases. An e-Science approach with life scientist friendly interfaces. BMC Bioinf 11(1):548

66. Venturi N, Rovelli A, Parini R, Menni F, Brambillasca F, Bertagnolio F, Uziel G, Gatti R, Filocamo M, Donati MA, Biondi A, Goldwurm S. (2002) Molecular analysis of 30 mucopolysaccharidosis type I patients: evaluation of the mutational spectrum in Italian population and identification of 13 novel mutations. Hum Mutat 20(3):231

67. Villani GR, Balzano N, Grosso M, Salvatore F, Izzo P, Di Natale P (1997) Mucopolysaccharidosis type II: identification of six novel mutations in Italian patients. Hum Mutat 10(1):71-75

68. Villani GR, Balzano N, Vitale D, Saviano M, Pavone V, Di Natale P (1999) Maroteaux-Lamy syndrome: five novel mutations and their structural localization. Biochim Biophys Acta 1453(2):185-192

69. Weber B, Guo XH, Wraith JE, Cooper A, Kleijer WJ, Bunge S, Hopwood JJ (1997) Novel mutations in Sanfilippo A syndrome: implications for enzyme function. Hum Mol Genet 6(9):1573-1579

70. Weber B, Guo X-H, Kleijer WJ, van de Kamp JJ, Poorthuis BJ, Hopwood JJ (1999) Sanfilippo type B syndrome (mucopolysaccharidosis III B): allelic heterogeneity corresponds to the wide spectrum of clinical phenotypes. Eur J Hum Genet 7(1):34- 44

71. Whitley CB, Anderson RA, Aronovich EL, Crotty PL, AnyaneYeboa K, Russo D, Warburton D (1993) Caveat to genotypephenotype correlation in mucopolysaccharidosis type II: discordant clinical severity of R468W and R468Q mutations of the iduronate2-sulfatase gene. Hum Mutat 2(3):235-237

72. Yassaee VR, Hashemi-Gorji F, Miryounesi M, Rezayi A, Ravesh Z, Yassaee F, Salehpour S (Nov. 2017) Clinical, biochemical and molecular features of Iranian families with mucopolysaccharidosis: a case series. Clin Chim Acta 474:88-95

73. Yogalingam G, Guo XH, Muller VJ, Brooks DA, Clements PR, Kakkis ED, Hopwood JJ (2004) Identification and molecular characterization of alpha-L-iduronidase mutations present in mucopolysaccharidosis type I patients undergoing enzyme replacement therapy. Hum Mutat 24(3):199-207

74. Zanetti A, Tomanin R, Rampazzo A, Rigon C, Gasparotto N, Cassina M, Clementi M, Scarpa M. (2014) A Hunter patient with a severe phenotype reveals two large deletions and two duplications extending 1.2 Mb distally to IDS locus. JIMD Rep 17:13-21

75. Zhao HG, Li HH, Bach G, Schmidtchen A, Neufeld EF (1996) The molecular basis of Sanfilippo syndrome type B. Proc Natl Acad Sci U S A 93(12):6101-6105

76. Zhao HG, Aronovich EL, Whitley CB (1998) Genotype-phenotype correspondence in Sanfilippo syndrome type B. Am J Hum Genet 62(1):53-63

Publisher's note Springer Nature remains neutral with regard to jurisdictional claims in published maps and institutional affiliations. 


\section{Affiliations}

\section{Alessandra Zanetti ${ }^{1,2}$. Francesca D'Avanzo ${ }^{1,2}$. Laura Rigon ${ }^{1,2}$. Angelica Rampazzo ${ }^{1}$. Daniela Concolino ${ }^{3}$. Rita Barone ${ }^{4}$ - Nicola Volpi ${ }^{5}$ - Lucia Santoro ${ }^{6}$. Susanna Lualdi ${ }^{7}$. Francesca Bertola ${ }^{8}$. Maurizio Scarpa ${ }^{1,2}$. Rosella Tomanin ${ }^{1,2}$}

1 Laboratorio di Diagnosi e Terapia delle Malattie Lisosomiali, Department of Women's and Children's Health, University of Padova, Padova, Italy

2 Fondazione Istituto di Ricerca Pediatrica Città della Speranza, Padova, Italy

3 Department of Pediatrics, University of Catanzaro, Catanzaro, Italy

4 Department of Clinical and Experimental Medicine, Child Neurology and Psychiatry, University of Catania,

Catania, Italy
5 Department of Life Sciences, University of Modena and Reggio Emilia, Modena, Italy

6 Department of Clinical Sciences, Division of Pediatrics, Polytechnic University of Marche, Ospedali Riuniti, Presidio Salesi, Ancona, Italy

7 Laboratorio di Genetica Medica e Biobanche, Istituto Giannina Gaslini, Genoa, Italy

8 School of Medicine and Surgery, University of Milano Bicocca, Monza, Italy 